OPEN ACCESS

Edited by:

Davide Settembre Blundo, Rey Juan Carlos University, Spain

Reviewed by:

Giulia Caruso,

University of Studies G. d'Annunzio Chieti and Pescara, Italy

Claudio Sassanelli,

Politecnico di Milano, Italy

*Correspondence:

Giulia Bondi

Giulia.Bondi@teagasc.ie

TORCID:

Giulia Bondi

orcid.org/0000-0002-8896-0262

Owen Fenton

orcid.org/0000-0001-7119-2538

David P. Wall

orcid.org/0000-0002-2365-0335

Specialty section:

This article was submitted to

Circular Economy

a section of the journal

Frontiers in Sustainability

Received: 03 November 2020 Accepted: 31 December 2020

Published: 01 February 2021

Citation:

Bondi G, Fenton O, Sawdekar P, Keane $H$ and Wall DP (2021) Potential of Lacto-Gypsum as an Amendment to Build Soil Quality,

Front. Sustain. 1:625727. doi: 10.3389/frsus.2020.625727

\section{Potential of Lacto-Gypsum as an Amendment to Build Soil Quality}

\author{
Giulia Bondi ${ }^{1 \star}$, Owen Fenton ${ }^{1 \dagger}$, Parikshit Sawdekar ${ }^{2}$, Hilda Keane ${ }^{2}$ and David P. Wall ${ }^{1 \dagger}$ \\ ${ }^{1}$ Teagasc Crops, Environment and Land-Use Research Centre, Wexford, Ireland, ${ }^{2}$ Glanbia Ireland Ltd., Thurles, Ireland
}

Strategies for the use of amendments on agricultural soils are needed to help build resilience against potential soil threats. Gypsum is commonly applied to improve soil quality and nutrient supply. However, the sustainability and environmental safety of some gypsum sources is uncertain. This study aims to i. characterize a new by-product, lacto-gypsum, derived from a dairy whey side stream over a 1 year pilot production cycle and ii. assess the temporal variability of the raw form of lacto-gypsum and the stability of its physico-chemical and compositional properties when stored under three potential storage regimes. Results showed that lacto-gypsum compares favorably with conventional equivalents in terms of nutrient and trace element concentrations and represents an environmentally safe material free of contaminants. Storage form did not affect its main physico-chemical characteristics over time and the raw lacto-gypsum remained stable up to 20 days when stored at $4^{\circ} \mathrm{C}$. In contrast to conventional gypsum, the lacto-gypsum had very low pH. In general this new lacto-gypsum shows potential as a suitable product for use as a soil amendment or as an acidification agent for animal slurry to reduce ammonia gas emissions during storage. However, further evaluation of this by-product in real life scenarios is required.

Keywords: dairy whey side streams, dairy residues bio-refinery, gypsum, soil quality (SQ), soil amendments, circular economy

\section{INTRODUCTION}

The application of amendments to agricultural soils can help to build soil resilience against potential soil threats such as soil compaction, erosion, soil fertility or organic matter (OM) loss (Amoah-Antwi et al., 2020). One option is natural/mined gypsum, which has been used for decades to improve soil structure (Hamza and Anderson, 2002, Herrero et al., 2009, Chen and Dick, 2011, Chi et al., 2012). From a chemical perspective gypsum is proven to be an excellent source of Ca and S both of which are beneficial for plant growth (Dick et al., 2006; Batool et al., 2015; Walia and Dick, 2016). The Ca present in gypsum binds OM to clay, thereby protecting it and preventing carbon (C) losses (Walia and Dick, 2018). In addition, gypsum amendment overcomes problems with subsoil acidity and aluminum toxicity in some soils (Toma et al., 1999, Sumner, 1993; Farina et al., 2000). Application of gypsum as amendment for the treatment of alkali and saline soils is also a widely used practice (Oster and Frenkel, 1980; Shainberg et al., 1989; Dick et al., 2006). In terms of physical quality, the $\mathrm{Ca}$ in gypsum increases the aggregation potential of soil particles making the soil more resilient against compaction (Watts and Dick, 2014; Walia and Dick, 2019). 


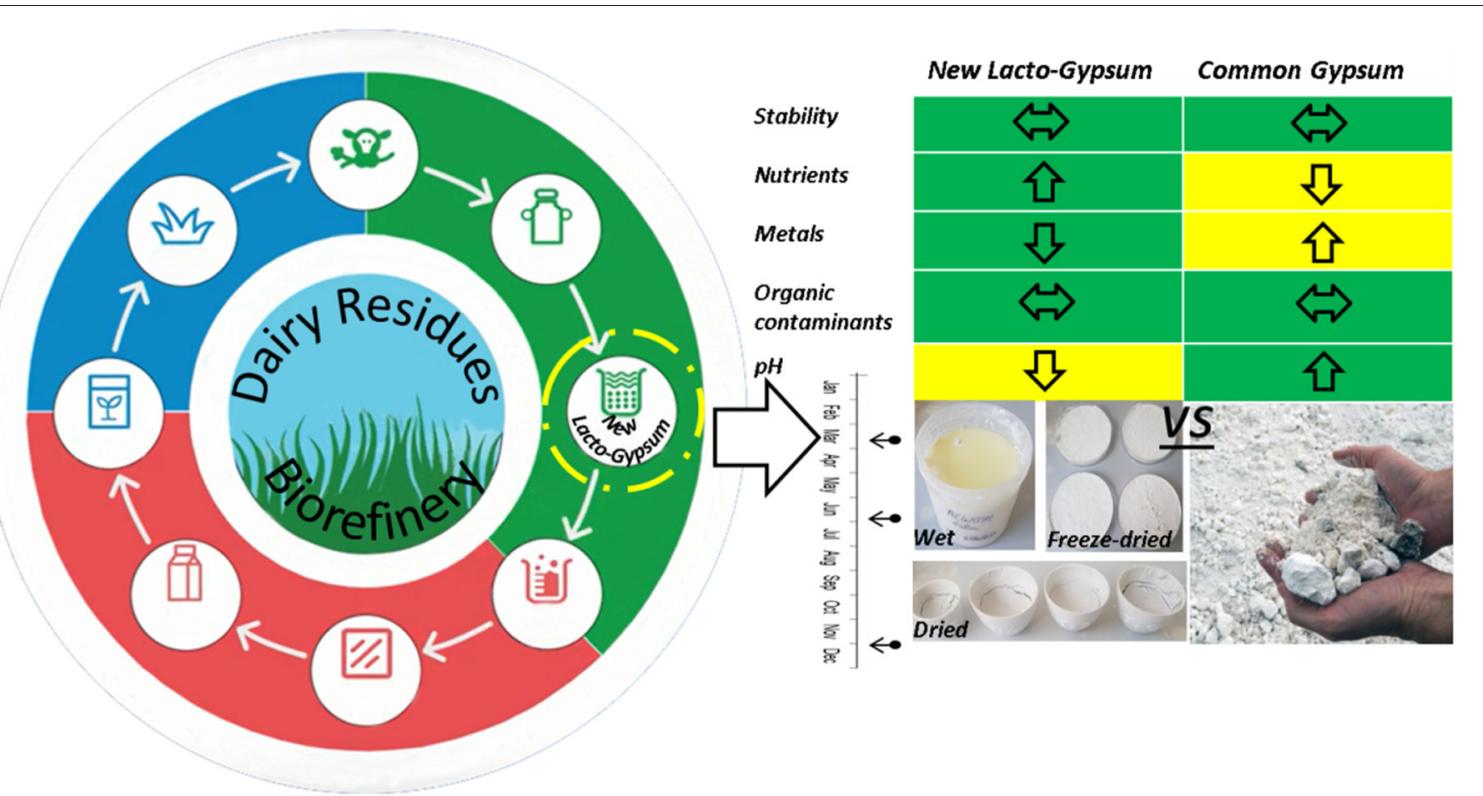

GRAPHICAL ABSTRACT | Graphical representation of the lacto-gypsum production through circular economy approach and research design adopted in this study.

Gypsum comes in many different forms e.g., the gypsum used in soils is typically natural gypsum, which is mined or quarried (calcium sulfate dihydrate in dry powder form containing 80$98 \%$ product as particles $<150 \mu \mathrm{m}$ ). Other commercial sources of gypsum (synthetic) as a by-product from the food, construction waste and glass crystal industries (Fauziah et al., 1996; Illera et al., 2004), and flue gas desulfurization gypsum are also available (Dick et al., 2006; Wang and Yang, 2018; Koralegedara et al., 2019). However, the sustainability of supply and environmental safety of some gypsum sources is uncertain (Watts and Dick, 2014) and any new source of gypsum must be analyzed for toxicity prior usage on agricultural soils, especially for food production. Furthermore, all commercially, gypsum sources must comply with the European regulations, such as the EU fertilizer regulation, prior application to agricultural soils.

Within the agricultural industry and in particular in dairy industry, there is much scope to valorise residues produced during milk processing and to reuse these by-products as inputs to the production system on farms. The global milk industry yearly produces an enormous volume of dairy residues. Ireland, is one of the main producers of cow's milk in Europe (with 5\% of milk production (Eurostat, 2019), that inevitably contributes to the progressive increase of dairy residues (DAFF, 2011; Finnegan et al., 2017). New technologies, such as integrated dairy processing residue bio-refineries are being implemented to convert dairy residues to valuable by-products following a circular approach. Currently, dairy residues treatment consists on the removal of fats, oils, greases, organic materials, suspended solids and nutrients such as phosphorous (Ryan and Walsh, 2016; Ashekuzzaman et al., 2019). In Ireland, research is ongoing toward the development of an industrial-scale biorefinery which aims to valorise over 25,000 tons (100\% dry matter) of undervalued dairy processing side streams per annum. This includes the extraction and reuse of excess whey permeate and de-lactosed whey permeate as well as several added value products for growing global markets e.g., LLactic acid (LA), polylactic acid (PLA), minerals for human nutrition, and biobased fertilizers. By-products arising from these dairy side streams include calcium sulfate, commonly known as lacto-gypsum.

Therefore, the aim of this study is to:

- provide for the first time characterization information of this new lacto-gypsum and assess its potential to be used as a soil amendment by comparing its physico-chemical and compositional characteristics with conventional gypsum used in agriculture;

- assess the variability of the lacto-gypsum produced at pilot plant scale over 1 year production cycle and evaluate its stability in storage post production. Specifically, we tested: i. the variability in lacto-gypsum properties under three potential storage regimes and ii. the temporal variability of raw lacto-gypsum properties post production.

\section{MATERIALS AND METHODS}

This section describes the process of lacto-gypsum production from the industrial whey permeate treatment and the sampling strategy at pilot plant and laboratory scale.

\section{Lacto-Gypsum Production and Characterization}

Dairy whey side-streams are treated with Glanbia Ireland through a novel process for demineralization and partially cleaning recovered lactose from the whey permeate streams 
which are utilized as fermentation substrate for Lactic acid microbial production. Whey permeate is a low value by-product of whey processing from dairy industry. Whey permeate is rich in lactose which makes it a potentially sustainable substrate for lactic acid bacterial fermentation and it is currently used in cattle feed with limited exploration of other commercial uses. As a part of lactic acid downstream purification process, bacterial cells are removed after complete fermentation using centrifuge from calcium lactate fermentation broth. In the recovery phase, the fermentation broth containing calcium lactate is neutralized with $96 \%$ sulphuric acid to produce calcium sulfate (gypsum) and a free form of lactic acid is obtained. The gypsum precipitates in fermentation broth due to sulphuric acid neutralization reaction and this insoluble gypsum is separated by belt filtration method
(Morrissey et al., 2019). In this process, the calcium sulfate is recovered as an additional by-product called lacto-gypsum. The post-gypsum liquor is subjected to a series of steps to purify the lactic acid. The developed process removes all forms of impurities like proteins, color and minerals and at the end, a polymer grade lactic acid is achieved as final product. Figure 1 show a graphical representation of the treatment of whey permeate and the production of lacto-gypsum.

The lacto-gypsum evaluated in this study was raw lactogypsum by-product produced at the Glanbia Ireland's biorefinery pilot plant at Lisheen mine, Co. Tipperary, Ireland, between autumn 2018 and summer 2019. Three different batches of lacto-gypsum were produced during the optimization of the pilot plant process over a 1-year period, as follows:

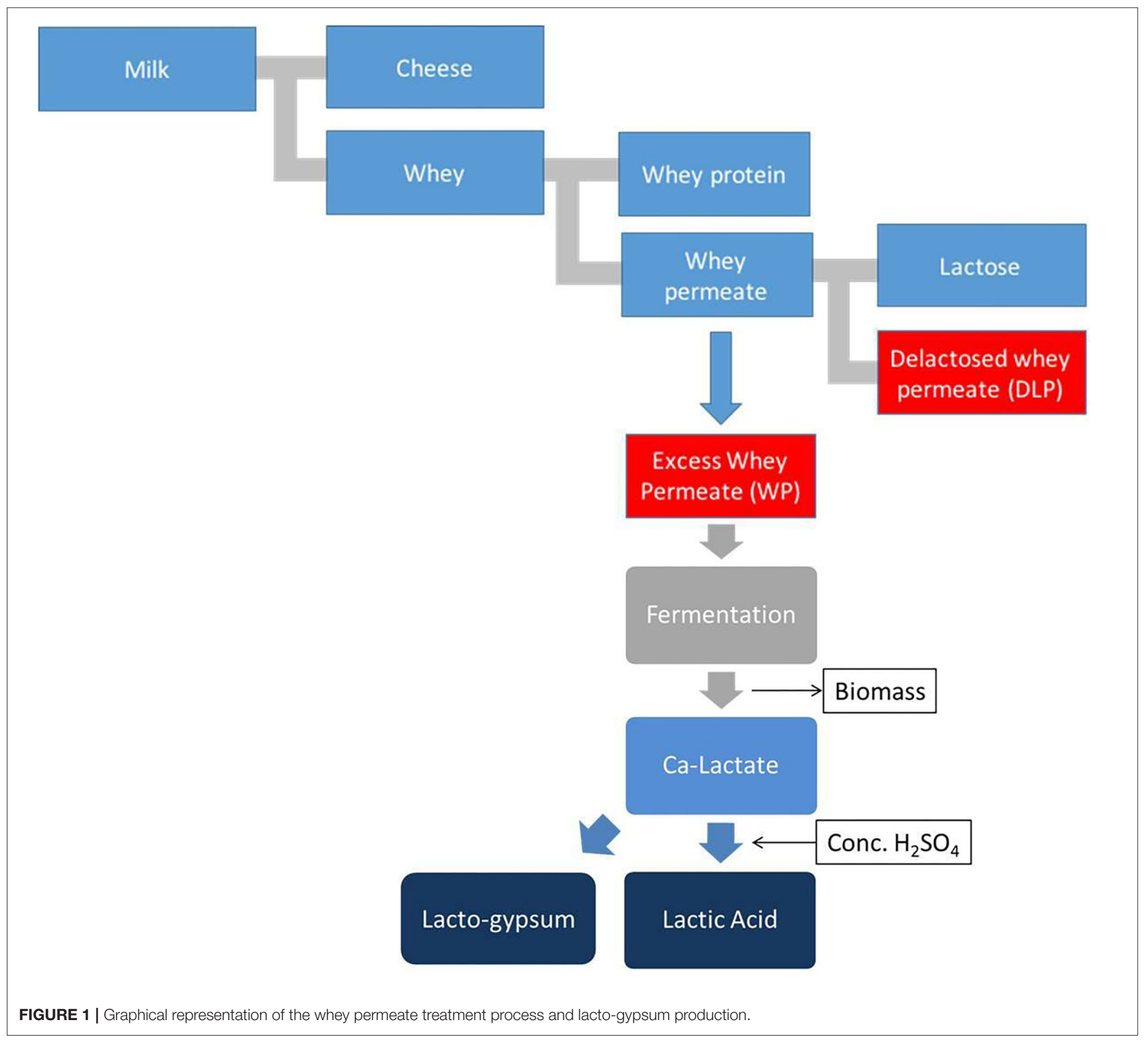


- Gy 1: Batch 1-November 2018;

- Gy 2: Batch 2-April 2019;

- Gy 3: Batch 3-June 2019.

These three lacto-gypsum batches Gy1-3 correspond to the end (Nov), start (April) and middle (June) of the typical milk production season for a spring calving dairy cow herd, which dominate in Irish systems. At each of these times, three separate replicate samples of about $5 \mathrm{~kg}$ each of raw lacto-gypsum were collected at the end of the gypsum separation process line for each sampling date (i.e., from each batch). The samples were placed in sealed containers and kept cool $\left(4^{\circ} \mathrm{C}\right)$. An initial compositional analysis was conducted on these samples at the Lisheen Analytical Laboratory following which they were sent directly to Teagasc Johnstown Castle Laboratories for physico-chemical analysis and further research on lacto-gypsum storability and effects of storage forms. On arrival at the lab each lacto-gypsum sample was in a semiliquid form where two phases were evident; a liquid phase at the top with a yellowish color and with some suspension greasy material and a settled solid phase toward the bottom of the container. The samples were stored at $4^{\circ} \mathrm{C}$, homogenized uniformly within 1-2 days and three raw subsamples were taken, corresponding to storage time $1(\mathrm{~T})$ and transformed/analyzed in three different forms: (i) Wet (raw) sample (W); (ii) Freeze dried sample (F); (iii) Dried sample (D).

The remaining raw sample was stored at $4^{\circ} \mathrm{C}$ and after a further 20 days was homogenized and subsampled again and the transformation/analyses were repeated for storage time 2 (T2).

\section{Lacto-Gypsum Characterization: Samples Preparation and Analysis}

The following analyses were performed on the T1 and T2 subsamples corresponding to the replicate samples collected from each lacto-gypsum batch Gy1-3.

$\mathrm{pH}$ was determined in the raw subsamples using a probe after stirring (Byrne, 1979).

(i) about 200-400 g of raw lacto-gypsum was transferred into petri dishes for freezing $\left(-20^{\circ} \mathrm{C}\right)$ and subsequently, freeze dried using ScanVac (CoolSafe 55-9 Pro) freeze dryer at $-55^{\circ} \mathrm{C}$ for about $24-48 \mathrm{~h}$.

(ii) about $200 \mathrm{~g}$ of raw lacto-gypsum was dried for about $24 \mathrm{~h}$ at $105^{\circ} \mathrm{C}$ in an oven.

The freeze dried and the dried samples were pulverized in a mixer mill (Retsch MM200) with a vibrational frequency of $25 \mathrm{~Hz}$ for $1 \mathrm{~min}$. The resulting powder samples were stored in falcon tubes at room temperature for analysis; the raw sample leftover was stored in the fridge at $4^{\circ} \mathrm{C}$.

In the three forms, (i). Wet sample (W); (ii). Freeze dried sample (F); (iii). Dried sample (D), the following analysis were performed:

Total carbon (TC), total nitrogen (TN) were determined by dry combustion using a CN LECO FP 2000 analyser (LECO Corp., St. Joseph, MI). The concentrations of nutrients [phosphorus $(\mathrm{P})$, potassium $(\mathrm{K})$, magnesium $(\mathrm{Mg})$, sulfur $(\mathrm{S})$, sodium $(\mathrm{Na})$, and calcium $(\mathrm{Ca})$ ], and metals [arsenic (As), cadmium $(\mathrm{Cd})$, chromium $(\mathrm{Cr})$, copper $(\mathrm{Cu})$, nickel $(\mathrm{Ni})$, lead $(\mathrm{Pb})$, zinc $(\mathrm{Zn})$, aluminum $(\mathrm{Al})$, iron $(\mathrm{Fe})$, cobalt $(\mathrm{Co})$, molybdenum (Mo) and manganese (Mn)] were determined by an Agilent 5100 synchronous vertical dual view inductively coupled plasma optical emission spectrometer (Agilent 5100 ICP-OES) following the microwave-assisted acid digestion (USEPA, 1996).

Dry matter (DM) percentage of the lacto-gypsum samples was determined by weight difference post oven drying at $105^{\circ} \mathrm{C}$. Organic matter (OM) was measured as the loss-on-ignition of the dried residue at $550^{\circ} \mathrm{C}$ in a muffle furnace (Storer, 1984).

Volatile organic acids (VFAs) and sugars were assessed on the wet sample by using high-performance liquid chromatography system equipped with a refractive-index detector (HPLC, Agilent 1200, Japan).

\section{Statistical Analyses}

STATISTICA 12.0 software (StatSoft Inc., Tulsa, Oklahoma, USA) was used for all statistical analysis. Factorial ANOVA was used to evaluate the differences $(p<0.05)$ between batch (Gy1, Gy2 and Gy3), form (Dried-D; Freeze-dried-F; and Wet-W) and time (T1 and $\mathrm{T} 2$ ) for dry matter, organic matter, $\mathrm{pH}$, major nutrients and trace elements. A one-way ANOVA was applied for the analysis of organic acids and sugars to test differences between batches (Gy1, Gy2, and Gy3). Differences between treatments were tested using Tukey's comparison test $(p \leq 0.05)$. The tests were performed to 3 samples for each treatment and values were reported as average \pm standard deviation. Principal Component Analysis (PCA) was used to assess the heterogeneity of the data.

\section{RESULTS AND DISCUSSION}

A full characterization of different gypsum sources and the new lacto-gypsum has been investigated and described below.

\section{Conventional Gypsum vs. Lacto-Gypsum Characteristics: Physico-Chemical Composition}

In the past, commonly used forms of gypsum, in particular natural/mined gypsum and flu-gas desulfurization (FGD) gypsum, have been fully characterized and evaluated as amendments for soils, and have been proven to improve soil structure and soil quality (Table 1). A comparison between existing literature data on physico-chemical characteristics of different gypsum types and the new lacto-gypsum has been performed in order to identify the main differences for potential use. Full physico-chemical composition of existing forms of gypsum and the new lacto-gypsum are reported in Tables 1, 2.

The results show a very low $\mathrm{pH}$ for the lacto-gypsum with respect to the most commonly used gypsum types (average $\mathrm{pH}$ for lacto-gypsum of 2.7 vs. natural gypsum and FGD gypsum of pH 6.5 and 7.5, respectively) (Tables 1, 2). This acidity was due to the presence of lactic acid (Table 2) carried forward into the lacto-gypsum by-product in the purification process.

This characteristic reduces to a certain extent the potential of this product to be land-spread as it is, especially in very acidic soils. However, the acidic nature of the lacto-gypsum could be used to acidify other media. One example in agriculture 
TABLE 1 | Characterization of different Gypsum types in use and lacto-gypsum tested in this study (average).

\begin{tabular}{|c|c|c|c|c|c|c|c|c|c|c|}
\hline & \multirow[b]{2}{*}{ Parameters } & \multirow[b]{2}{*}{ Unit } & \multirow[b]{2}{*}{ Natural gypsum $^{a}$} & \multicolumn{5}{|c|}{ Gypsum type } & \multicolumn{2}{|c|}{ EU limit values } \\
\hline & & & & Mined gypsum ${ }^{b}$ & Natural Gypsum ${ }^{c}$ & $\begin{array}{c}\text { FGD } \\
\text { gypsum }^{\mathrm{d}, \mathrm{e}}\end{array}$ & $\begin{array}{c}\text { FGD } \\
\text { gypsum }\end{array}$ & $\begin{array}{l}\text { Lacto- } \\
\text { Gypsum }\end{array}$ & EU limit soil ${ }^{h}$ & EU limit sludge \\
\hline \multirow{12}{*}{$\begin{array}{l}\text { Major } \\
\text { nutrients }\end{array}$} & $\mathrm{pH}$ & & - & - & 6.5 & 7.5 & - & 2.7 & - & - \\
\hline & EC & $\mathrm{ms} \mathrm{cm}^{-1}$ & - & - & 7.5 & 2.6 & - & - & - & - \\
\hline & DM & $\%$ & - & - & - & - & - & 44.9 & - & - \\
\hline & OM & $\%$ & - & - & - & - & - & 9.5 & - & - \\
\hline & Total C & $\%$ & - & - & 1.29 & 0.16 & - & 1.5 & - & - \\
\hline & Total N & $\%$ & - & - & 0.13 & 0.01 & - & 0.4 & - & - \\
\hline & Total P & $\mathrm{mg} \mathrm{kg}^{-1}$ & $<8.32$ & 1,600 & $<100$ & $<100$ & 141 & 903.8 & - & - \\
\hline & Total K & $\mathrm{mg} \mathrm{kg}^{-1}$ & 223 & 80 & 500 & $4,400-6,500$ & $800-1,500$ & 992.1 & - & - \\
\hline & Total Mg & $\mathrm{mg} \mathrm{kg}^{-1}$ & 6.58 & 10 & 1300 & $6,500-22,800$ & $\begin{array}{c}3,800- \\
16,2000\end{array}$ & 109.9 & - & - \\
\hline & Total $\mathrm{Na}$ & $\mathrm{mg} \mathrm{kg}^{-1}$ & 52 & 100 & - & - & - & 687.6 & - & - \\
\hline & Total Ca & $\mathrm{g} \mathrm{kg}^{-1}$ & 196.7 & 218 & 247 & $163-272$ & $241-412$ & 696 & - & - \\
\hline & Total S & $\mathrm{g} \mathrm{kg}-1$ & 154.4 & 18 & 207 & 104-167 & $82-183$ & 160.9 & - & - \\
\hline \multirow{15}{*}{$\begin{array}{l}\text { Trace } \\
\text { elements }\end{array}$} & $\mathrm{Cr}$ & $\mathrm{mg} \mathrm{kg}^{-1}$ & - & - & - & - & $11.7-25.3$ & 0.6 & - & - \\
\hline & $\mathrm{Cu}$ & $\mathrm{mg} \mathrm{kg}^{-1}$ & - & 12 & $<0.8$ & $<0.1-7.6$ & $16.5-913$ & 0.3 & 140 & 1,750 \\
\hline & $\mathrm{Ni}$ & $\mathrm{mg} \mathrm{kg}^{-1}$ & - & - & 2.3 & $1.5-17.3$ & $16.4-58.2$ & nd & 75 & 400 \\
\hline & $\mathrm{Zn}$ & $\mathrm{mg} \mathrm{kg}^{-1}$ & $<0.78$ & 1.4 & 6.1 & $2.5-14.3$ & 55-389 & 4.3 & 300 & 40,00 \\
\hline & Al & $\mathrm{mg} \mathrm{kg}^{-1}$ & - & - & 1,500 & $5,500-12,300$ & $6,000-28,000$ & 22.3 & - & - \\
\hline & $\mathrm{Fe}$ & $\mathrm{mg} \mathrm{kg}^{-1}$ & 1.0 & 830 & 900 & $1,700-14,900$ & $7,000-27,000$ & 16.8 & - & - \\
\hline & $\mathrm{Mn}$ & $\mathrm{mg} \mathrm{kg}^{-1}$ & - & 0.5 & 31 & $90-403$ & $63-625$ & 1.3 & - & - \\
\hline & Mo & $\mathrm{mg} \mathrm{kg}^{-1}$ & 1.13 & - & 0.8 & $0.5-14.7$ & $<0.02-25.3$ & nd & - & - \\
\hline & $\mathrm{Pb}$ & $\mathrm{mg} \mathrm{kg}^{-1}$ & - & 3.2 & 1.2 & $3-218$ & $5-28$ & nd & 300 & 1,200 \\
\hline & As & $\mathrm{mg} \mathrm{kg}^{-1}$ & - & - & $<2.6$ & $<2.6$ & $5.4-213$ & nd & - & - \\
\hline & $\mathrm{Cd}$ & $\mathrm{mg} \mathrm{kg}^{-1}$ & 0.02 & - & 0.3 & $<0.01$ & $0.5-3.9$ & nd & 3 & 40 \\
\hline & Co & $\mathrm{mg} \mathrm{kg}^{-1}$ & - & - & - & - & $3.9-27.3$ & nd & - & - \\
\hline & Se & $\mathrm{mg} \mathrm{kg}^{-1}$ & - & - & $<1.2$ & 2.1 & $2.3-4.6$ & - & - & - \\
\hline & $\mathrm{Hg}$ & $\mathrm{mg} \mathrm{kg}^{-1}$ & - & - & 0.02 & 0.25 & & - & - & - \\
\hline & B & $\mathrm{mg} \mathrm{kg}^{-1}$ & 14.3 & - & 168 & $98-175$ & & - & - & - \\
\hline
\end{tabular}

aWalia and Dick (2019).

${ }^{b}$ Kauppila and Pietola (2013).

cMupambwa et al. (2015).

${ }^{d}$ Baligar et al. (2011).

eWang and Yang (2018)

${ }^{{ }}$Kost et al. (2018).

g Koralegedara et al. (2019).

${ }^{\text {h}}$ Ashekuzzaman et al. (2019) and EEC (1986).

Concentration of nutrients and trace elements, comparison with European Union (EU) regularity. 
TABLE 2 | Major nutrient content, trace elements, organic acids, and sugars in lacto-gypsum.

\begin{tabular}{|c|c|c|c|c|c|c|c|c|c|}
\hline & \multirow[b]{2}{*}{ Parameters } & \multirow[b]{2}{*}{ Unit } & \multicolumn{2}{|c|}{ Gy1 } & \multicolumn{2}{|c|}{ Gy2 } & \multicolumn{2}{|c|}{ Gy3 } & \multirow[b]{2}{*}{ Average } \\
\hline & & & T1 & T2 & T1 & T2 & T1 & T2 & \\
\hline \multirow[t]{11}{*}{ Major nutrients } & $\mathrm{pH}$ & & $3.0 \pm 0.0 \mathrm{~ns}$ & $3.1 \pm 0.0 \mathrm{~ns}$ & $2.8 \pm 0.0 n s$ & $2.7 \pm 0.0 n s$ & $2.3 \pm 0.0 \mathrm{~ns}$ & $2.5 \pm 0.0 \mathrm{~ns}$ & 2.7 \\
\hline & DM & $\%$ & $40.6 \pm 3.2 \mathrm{~ns}$ & $41.4 \pm 3.3 \mathrm{~ns}$ & $49.2 \pm 3.9 n s$ & $44.9 \pm 3.6 n s$ & $46.8 \pm 3.7 \mathrm{~ns}$ & $46.2 \pm 3.7 \mathrm{~ns}$ & 44.9 \\
\hline & OM & $\%$ & $5.2 \pm 0.4 a$ & $5.3 \pm 0.4 a$ & $11.8 \pm 0.9 b$ & $13.8 \pm 1.1 \mathrm{~b}$ & $13.1 \pm 1.0 \mathrm{~b}$ & $7.4 \pm 0.6 a$ & 9.5 \\
\hline & Total C & $\%$ & $1.7 \pm 0.2 \mathrm{bc}$ & $0.2 \pm 0.0 \mathrm{a}$ & $2.3 \pm 0.6 c$ & $2.5 \pm 0.4 c$ & $1.1 \pm 0.2 \mathrm{ab}$ & $1.1 \pm 0.3 a b$ & 1.5 \\
\hline & Total N & $\%$ & $0.2 \pm 0.0 a$ & $1.5 \pm 0.1 b$ & $0.2 \pm 0.0 a$ & $0.2 \pm 0.0 a$ & $0.2 \pm 0.1 a$ & $0.1 \pm 0.0 \mathrm{a}$ & 0.4 \\
\hline & Total P & $\mathrm{mg} \mathrm{kg}^{-1}$ & $949.0 \pm 195.2 \mathrm{bc}$ & $986.7 \pm 159.3 \mathrm{bc}$ & $1178.8 \pm 27.5 \mathrm{c}$ & $1172.6 \pm 183.8 \mathrm{c}$ & $625.1 \pm 105.7 a b$ & $510.6 \pm 49.4 a$ & 903.8 \\
\hline & Total K & $\mathrm{mg} \mathrm{kg}^{-1}$ & $749.1 \pm 97.0 \mathrm{a}$ & $837.7 \pm 122.8 \mathrm{a}$ & $1368.2 \pm 199.5 b$ & $1427.3 \pm 271.5 b$ & $837.4 \pm 164.4 a$ & $732.8 \pm 32.5 a$ & 992.1 \\
\hline & Total Mg & $\mathrm{mg} \mathrm{kg}^{-1}$ & $91.7 \pm 12.5 \mathrm{ac}$ & $97.1 \pm 11.8 \mathrm{ac}$ & $148.3 \pm 49.6 a b$ & $186.1 \pm 32.1 b$ & $73.5 \pm 17.6 \mathrm{c}$ & $62.3 \pm 1.3 c$ & 109.9 \\
\hline & Total Na & $\mathrm{mg} \mathrm{kg}^{-1}$ & $630.7 \pm 98.5 \mathrm{ac}$ & $597.2 \pm 101.7 a$ & $931.6 \pm 140.0 \mathrm{bc}$ & $1052.7 \pm 198.4 b$ & $506.0 \pm 80.7 a$ & $407.6 \pm 36.4 a$ & 687.6 \\
\hline & Total Ca & $\mathrm{g} \mathrm{kg}^{-1}$ & $1094.8 \pm 1585.2 \mathrm{ab}$ & $2303.9 \pm 600.8 b$ & $203.3 \pm 65.6 a$ & $183.2 \pm 38.7 a$ & $211.5 \pm 166.5 a$ & $179.0 \pm 33.8 \mathrm{a}$ & 696 \\
\hline & Total S & $\mathrm{g} \mathrm{kg}^{-1}$ & $158.7 \pm 66.8 \mathrm{~ns}$ & $187.8 \pm 47.4 \mathrm{~ns}$ & $155.9 \pm 49.6 n s$ & $125.4 \pm 31.4 \mathrm{~ns}$ & $214.2 \pm 40.7 \mathrm{~ns}$ & $123.6 \pm 24.9 \mathrm{~ns}$ & 160.9 \\
\hline \multirow[t]{12}{*}{ Trace elements } & $\mathrm{Cr}$ & $\mathrm{mg} \mathrm{kg}^{-1}$ & $0.3 \pm 0.2 \mathrm{~ns}$ & $0.4 \pm 0.1 \mathrm{~ns}$ & $0.6 \pm 0.1 \mathrm{~ns}$ & $0.8 \pm 0.7 \mathrm{~ns}$ & $0.7 \pm 0.1 \mathrm{~ns}$ & $0.7 \pm 0.2 \mathrm{~ns}$ & 0.6 \\
\hline & $\mathrm{Cu}$ & $\mathrm{mg} \mathrm{kg}^{-1}$ & $0.1 \pm 0.2 \mathrm{~ns}$ & $0.3 \pm 0.1 \mathrm{~ns}$ & $0.2 \pm 0.2 \mathrm{~ns}$ & $0.5 \pm 0.2 \mathrm{~ns}$ & $0.5 \pm 0.2 \mathrm{~ns}$ & $0.3 \pm 0.1 \mathrm{~ns}$ & 0.3 \\
\hline & $\mathrm{Ni}$ & $\mathrm{mg} \mathrm{kg}^{-1}$ & nd a & nd a & nd a & nd a & $2.8 \pm 1.0 \mathrm{~b}$ & nd a & nd \\
\hline & $\mathrm{Zn}$ & $\mathrm{mg} \mathrm{kg}^{-1}$ & $0.4 \pm 0.7 a$ & $1.0 \pm 0.0 \mathrm{a}$ & $9.9 \pm 2.9 b$ & $12.1 \pm 2.2 b$ & $1.6 \pm 0.4 a$ & $0.7 \pm 0.1 \mathrm{a}$ & 4.3 \\
\hline & Al & $\mathrm{mg} \mathrm{kg}^{-1}$ & $15.3 \pm 2.9 \mathrm{ac}$ & $15.3 \pm 2.7 \mathrm{ac}$ & $36.0 \pm 5.3 a b$ & $46.3 \pm 15.8 b$ & $10.1 \pm 7.6 \mathrm{c}$ & $11.0 \pm 2.0 \mathrm{c}$ & 22.3 \\
\hline & $\mathrm{Fe}$ & $\mathrm{mg} \mathrm{kg}^{-1}$ & $8.3 \pm 3.2 a$ & $9.5 \pm 1.7 \mathrm{a}$ & $26.4 \pm 5.3 b$ & $38.1 \pm 8.4 b$ & $5.9 \pm 4.7 \mathrm{a}$ & $12.6 \pm 1.8 \mathrm{a}$ & 16.8 \\
\hline & $\mathrm{Mn}$ & $\mathrm{mg} \mathrm{kg}^{-1}$ & $1.1 \pm 0.2 \mathrm{ac}$ & $1.1 \pm 0.2 \mathrm{ac}$ & $2.0 \pm 0.7 \mathrm{ab}$ & $2.4 \pm 0.2 b$ & $0.5 \pm 0.3 c$ & $0.8 \pm 0.0 c$ & 1.3 \\
\hline & Mo & $\mathrm{mg} \mathrm{kg}^{-1}$ & nd & nd & nd & nd & nd & nd & nd \\
\hline & $\mathrm{Pb}$ & $\mathrm{mg} \mathrm{kg}^{-1}$ & nd & nd & nd & nd & nd & nd & nd \\
\hline & As & $\mathrm{mg} \mathrm{kg}^{-1}$ & nd & nd & nd & nd & nd & nd & nd \\
\hline & $\mathrm{Cd}$ & $\mathrm{mg} \mathrm{kg}^{-1}$ & nd & nd & nd & nd & nd & nd & nd \\
\hline & Co & $\mathrm{mg} \mathrm{kg}^{-1}$ & nd & nd & nd & nd & nd & nd & nd \\
\hline \multirow[t]{9}{*}{ Organic Acids } & Lactic Acid & $\mathrm{mg} \mathrm{I}^{-1}$ & $41531 b$ & - & $36215 a$ & - & $60047 c$ & - & 45,931 \\
\hline & Citric Acid & $\mathrm{mg} \mathrm{I}^{-1}$ & nd a & - & $1055 b$ & - & $1336 \mathrm{c}$ & - & - \\
\hline & Malic Acid & $\mathrm{mg} \mathrm{I}^{-1}$ & nd & - & nd & - & nd & - & nd \\
\hline & Pyruvic Acid & $\mathrm{mg} \mathrm{I}^{-1}$ & nd & - & nd & - & nd & - & nd \\
\hline & Succinic Acid & $\mathrm{mg} \mathrm{I}^{-1}$ & nd a & - & nd a & - & $193 \mathrm{~b}$ & - & - \\
\hline & Formic Acid & $\mathrm{mg} \mathrm{I}^{-1}$ & nd a & - & nd a & - & $446 b$ & - & - \\
\hline & Acetic Acid & $\mathrm{mg} \mathrm{I}^{-1}$ & nd a & - & nd a & - & $603 b$ & - & - \\
\hline & Propionic Acid & $\mathrm{mg} \mathrm{I}^{-1}$ & nd & - & nd & - & nd & - & nd \\
\hline & Butyric Acid & $\mathrm{mg} \mathrm{l}^{-1}$ & nd & - & nd & - & nd & - & nd \\
\hline \multirow[t]{3}{*}{ Sugars } & Lactose & $\mathrm{mg} \mathrm{I}^{-1}$ & $1413 c$ & - & nd a & - & $502 b$ & - & - \\
\hline & Glucose & $\mathrm{mg} \mathrm{l}^{-1}$ & nd & - & nd & - & nd & - & nd \\
\hline & Galactose & $\mathrm{mg} \mathrm{l}^{-1}$ & nd a & - & $278 b$ & - & $834 c$ & - & - \\
\hline
\end{tabular}

nd, not detectable; nd, concentrations of $\mathrm{Ni}, \mathrm{Mo}, \mathrm{Pb}, \mathrm{As}, \mathrm{Cd}$, Co were $<0.6,<0.5,<2,<1.5,<0.15,<0.3 \mathrm{mg} \mathrm{kg}^{-1}$, respectively.

Statistical significance within treatments is indicated by different letter, for non-significance: same/common letter or ns is present. 
is the acidification of animal slurries. A reduction of $\mathrm{pH}$ of slurry has been shown to reduce ammonia gas emissions and also to inhibit bacterial processes involved in the release of greenhouse gases (GHG) (Sommer and Husted, 1995). Kavanagh et al. (2019) evaluated the efficacy of common chemical byproduct amendments for acidification of stored slurry/manure for the purposes of reducing ammonia gas emissions. While lacto-gypsum was not evaluated in this previous study, the low $\mathrm{pH}$ may be conducive to achieve the desired reduction in slurry $\mathrm{pH}(<5.5)$ while not introducing contaminants such as heavy metals etc. However, this practice can be potentially hazardous for the operator due to the possible liberation of hydrogen sulfide $\left(\mathrm{H}_{2} \mathrm{~S}\right)$ after mixing lacto-gypsum and slurry. Further research, including experiments to test different ratios of lacto-gypsum to slurry input, focusing on $\mathrm{H}_{2} \mathrm{~S}$ gas suppression measures (EC, 2002; Asakura, 2015) needs to be completed to assess lactogypsum potential as a slurry acidifications agent and its effects on slurry nutrient availability and health and safety.

Data for the main nutrients and trace elements vary considerably between the different gypsum types (Table $\mathbf{1}$ ). The lacto-gypsum shows low total $\mathrm{C}(1.5 \%)$ and total $\mathrm{N}$ $(0.4 \%)$, concentrations similar to the ones reported for natural gypsum (Mupambwa et al., 2015) but, in general, higher than values typically found in FGD gypsum (Wang and Yang, 2018) (Tables 1, 2).

Lacto-gypsum $\mathrm{P}, \mathrm{K}$, and $\mathrm{S}$ seem to be higher than the ranges reported for the conventional sources of gypsum such as natural gypsum and FGD gypsum (Tables 1, 2). However, these values were generally low compared to standard chemical fertilizer nutrient sources (Wall and Plunkett, 2016). In particular the P content was, in average, about ten times higher for the lacto gypsum compared to natural gypsum and FGD gypsum, and ranged from 510.6 to $1178.8 \mathrm{mg} \mathrm{kg}^{-1}$ within the three batches (Tables 1,2). The $S$ content in the lacto-gypsum was comparable to other gypsum types $\left(160 \mathrm{~g} \mathrm{~kg}^{-1}\right.$ vs. $207 \mathrm{~g} \mathrm{~kg}^{-1}$ for natural gypsum as per Mupambwa et al. (2015) and 104-167 or 82-183 g $\mathrm{kg}^{-1}$ for FGD gypsum as reported by Wang and Yang (2018) and Koralegedara et al. (2019), respectively).

Walia and Dick (2019) found that the addition of natural gypsum to soils helped to reduce the concentration of $\mathrm{P}$ in the leachate water collected. This would suggest that the gypsum is able to form Ca-P complexes which help to retain the nutrients in the soil and reduce P losses (Walia and Dick, 2019). The content of $\mathrm{P}$ in the lacto-gypsum, coupled with high Ca content (Table 2) may represent an opportunity to supply plant available $\mathrm{P}$ while reducing the potential risk of nutrient loss.

Walia and Dick (2019) also found that the combination of gypsum and a readily available form of $\mathrm{C}$, such as glucose, seemed to increase soluble P and S concentration in the soil, increasing the risk of losses. This is probably due to the high microbial activity promoted in the soil which enhanced the solubilisation of these two elements (Bondi et al., 2016). Further studies need to take into account the in-field application of lacto-gypsum in association with different sources of C commonly used in agricultural systems in Ireland. This will help to account for rates of application and interactions with mineral or organic fertilizers such as manure or slurry sources.
In general, these data indicated that the lacto-gypsum nutrient pool is similar to the one of other types of gypsum commonly used to soils as amendments.

The content of metals, in lacto-gypsum was also evaluated. Overall metals level was very low, with levels of heavy metals below the limits of detection for ICP-OES for Mo $<0.5$, As $<$ 1.5, $\mathrm{Co}<0.3, \mathrm{~Pb}<2.0$, and $\mathrm{Cd}<0.15$ and $\mathrm{Ni}<0.6 \mathrm{mg} \mathrm{kg}^{-1}$ (with the exception of Ni in Gy3T1) (Table 2). Furthermore, all the values for heavy metal concentrations in the lacto-gypsum were significantly lower than the thresholds recommended by EU regulations for soil and sludge confirming that heavy metal content is not a limiting factor in terms of toxicity for the land application of lacto-gypsum as an amendment (Table 1) (Ashekuzzaman et al., 2019). The average levels of $\mathrm{Cu}$ and $\mathrm{Zn}$ for lacto-gypsum were close to the lower range reported for FGD gypsum, while, average Mn content was in line with the natural gypsum values reported by Walia and Dick (2019) and Mupambwa et al. (2015) (Tables 1, 2). Very low levels of Fe and Al were also found. The concentration of Fe was $16.8 \mathrm{mg} \mathrm{kg}^{-1}$ for lacto-gypsum compared to a minimum value of $1,700 \mathrm{mg} \mathrm{kg}^{-1}$ for FGD gypsum; Al was $22.3 \mathrm{mg} \mathrm{kg}^{-1}$ for lacto-gypsum vs. $5,500 \mathrm{mg}$ $\mathrm{kg}^{-1}$ for FGD gypsum. However, FGD gypsum may typically contain higher levels of metals than mined gypsum or alternative forms of gypsum as result of the coal combustion process (Wang and Yang, 2018; Koralegedara et al., 2019). In general, these data showed that the lacto-gypsum can be considered to contribute low levels of metals, when used as a soil amendment.

\section{Storage Effect: Form and Time}

No significant differences were found between the three storage forms (D, F, and W) within the same batch and sampling time (T1, T2), for any of the physico-chemical parameters evaluated (Table 3). This indicates that the storage form evaluated did not alter the overall nutrient and chemical characteristics (Table 3). This is encouraging as it shows that the lacto-gypsum could be stored and used in its raw semiliquid form with no additional costs of transformation or processing for storage purposes. However, from a practical perspective, handling this raw form in large quantities could present difficulties for achieving a consistent product prior to transportation or even in land-spreading.

This initial short-term (20 days) temporal sampling study within the same batch indicates that the lacto-gypsum was relatively stable over time. This means that this by-product is able to keep its properties for at least 20 days when stored at $4{ }^{\circ} \mathrm{C}$. However, a change in the $\mathrm{Ca}$ content for Gyl between the two sampling times was found (Tables 2, 3). This was associated to a significant decrease of total $\mathrm{C}$ for this batch at the second sampling time (T2) (Table 2) which may indicate that the lacto-gypsum was losing $\mathrm{C}$ over time, likely as $\mathrm{CO}_{2}$ emission. Measuring $\mathrm{CO}_{2}$ efflux from the by-product would help identify if it remains biologically active. However, another potential explanation for variability in the $\mathrm{Ca}$ and $\mathrm{C}$ concentrations may have resulted from the wet lacto-gypsum material not being fully homogeneous as the sample was taken at the different times. Even with careful adherence to the sampling protocol this material was difficult to mix and to achieve a fully homogenous sample 
TABLE 3 | Factorial ANOVA used to evaluate the differences between lacto-gypsum batches, time of storage, form of storage and their interactions for dry matter, organic matter, $\mathrm{pH}$, major nutrients and trace elements.

\begin{tabular}{|c|c|c|c|c|c|}
\hline & & Form & Batch & Time & BatchTime \\
\hline & $\mathrm{pH}$ & ns & ns & ns & ns \\
\hline & $\mathrm{DM}$ & $\mathrm{ns}$ & $p<0.05$ & ns & ns \\
\hline & $\mathrm{OM}$ & ns & $p<0.05$ & $p<0.05$ & $p<0.05$ \\
\hline & Total C & ns & $p<0.05$ & $p<0.05$ & $p<0.05$ \\
\hline \multirow[t]{7}{*}{ Major nutrients } & Total N & ns & $p<0.05$ & $p<0.05$ & $p<0.05$ \\
\hline & Total P & ns & $p<0.05$ & ns & $\mathrm{ns}$ \\
\hline & Total K & ns & $p<0.05$ & ns & ns \\
\hline & Total Mg & ns & $p<0.05$ & ns & $\mathrm{ns}$ \\
\hline & Total $\mathrm{Na}$ & ns & $p<0.05$ & ns & $\mathrm{ns}$ \\
\hline & Total Ca & ns & $p<0.05$ & ns & $\mathrm{ns}$ \\
\hline & Total S & ns & ns & ns & ns \\
\hline \multirow[t]{12}{*}{ Trace elements } & $\mathrm{Cr}$ & ns & ns & ns & ns \\
\hline & $\mathrm{Cu}$ & ns & ns & ns & $p<0.05$ \\
\hline & $\mathrm{Ni}$ & ns & $p<0.05$ & $p<0.05$ & $p<0.05$ \\
\hline & $\mathrm{Zn}$ & ns & $p<0.05$ & ns & ns \\
\hline & Al & ns & $p<0.05$ & $\mathrm{~ns}$ & ns \\
\hline & $\mathrm{Fe}$ & ns & $p<0.05$ & $p<0.05$ & $\mathrm{~ns}$ \\
\hline & $\mathrm{Mn}$ & $\mathrm{ns}$ & $p<0.05$ & $\mathrm{~ns}$ & $\mathrm{~ns}$ \\
\hline & Mo & ns & $\mathrm{ns}$ & ns & ns \\
\hline & $\mathrm{Pb}$ & ns & ns & ns & ns \\
\hline & As & ns & ns & ns & ns \\
\hline & $\mathrm{Cd}$ & $\mathrm{ns}$ & $\mathrm{ns}$ & $\mathrm{ns}$ & $\mathrm{ns}$ \\
\hline & Co & ns & ns & ns & ns \\
\hline \multirow[t]{9}{*}{ Organic acids } & Lactic Acid & - & $p<0.05$ & - & - \\
\hline & Citric Acid & - & $p<0.05$ & - & - \\
\hline & Malic Acid & - & ns & - & - \\
\hline & Pyruvic Acid & - & ns & - & - \\
\hline & Succinic Acid & - & $p<0.05$ & - & - \\
\hline & Formic Acid & - & $p<0.05$ & - & - \\
\hline & Acetic Acid & - & $p<0.05$ & - & - \\
\hline & Propionic Acid & - & ns & - & - \\
\hline & Butyric Acid & - & ns & - & - \\
\hline \multirow[t]{3}{*}{ Sugars } & Lactose & - & $p<0.05$ & - & - \\
\hline & Glucose & - & $\mathrm{ns}$ & - & - \\
\hline & Galactose & - & $p<0.05$ & - & - \\
\hline
\end{tabular}

Significance at Tukey's test ( $p<0.05)$, No significance (ns).

One-way ANOVA used to evaluate the differences between lacto-gypsum batches for organic acids and sugars.

throughout, with some settling and flocculation taking place quickly. For these reasons a longer term study would be needed to improve the understanding of lacto-gypsum stability during longer term storage under different environmental conditions.

\section{Heterogeneity in Lacto-Gypsum Batches Tested Over a Year Pilot Scale}

Data analysis of physico-chemical parameters evaluated showed significant differences between the three batches of lactogypsum produced (Table 3 ). The continuous optimization of the industrial process at the pilot plant from which the lacto-gypsum was produced apparently led to somewhat heterogeneous material over 1 year pilot study. A crucial factor, during the optimization process, was the dosage of $\mathrm{H}_{2} \mathrm{SO}_{4}$ for precipitation of $\mathrm{CaSO}_{4}$ which had been adjusted at each time a batch was produced. The treatment applied to the fermentation broth led to a high precipitation of $\mathrm{CaSO}_{4}$ in $\mathrm{Gyl}$, confirmed by higher values of Ca (1094.8 $\mathrm{g} \mathrm{kg}^{-1}$ for Gy1, T1). The addition of sulphuric acid may also have contributed to pull down some other nutrients, in particular P, resulting in higher values for Gy1 and also Gy2 (949 $\mathrm{mg} \mathrm{kg}^{-1}$ for Gy1 and $1178.8 \mathrm{mg} \mathrm{kg}^{-1}$ for Gy2) (Tables 2, 3).

Gy2 differs from the other two batches for the major nutrients content, showing the highest values for both times of sampling in terms of OM, Total $\mathrm{C}, \mathrm{P}, \mathrm{K}, \mathrm{Mg}$, and $\mathrm{Na}$ (Table 2). Higher values of metals, in particular $\mathrm{Zn}, \mathrm{Al}$, and $\mathrm{Fe}$ (Table 2) were also found for this batch. Typically $\mathrm{Al}$ or $\mathrm{Fe}$ salts are used 
to remove nutrients during the wastewater treatment process (Øgaard and Brod, 2016; Ashekuzzaman et al., 2019). However, in this case the lacto-gypsum was a direct by-product from the pilot plant and did not receive post processing to remove associated nutrients and other contaminants, such as metal salts. The higher concentration of elements in Gy2 was likely due to the addition of higher levels of $\mathrm{H}_{2} \mathrm{SO}_{4}$ during the acidification step of the process which promoted their precipitation into the final by-product. Furthermore, fluctuations of these elements can be due to differences in the chemical composition of the whey permeate generated and used in these batch experiments over time. Assuming the land spreading of a product similar to $\mathrm{Gy} 2$, it is likely that the $\mathrm{Al}$ or Fe present will be transferred to the soil. While, in general, these metal values remain very low (Peyton et al., 2016), it is good practice that agricultural soils are managed so that heavy metal immobilization is optimized prior to application of additional sources of metals. This includes the addition of the right amount of organic matter. The combination of lacto-gypsum with a $\mathrm{C}$ source in the soil, e.g., can help control the metal content by changing the soil chemical properties and its ability to chelate contaminants (Plaza et al., 2009). At the same time the $\mathrm{Ca}$ content of the lacto-gypsum is known to benefit soil aeration and infiltration rate and, in general, soil physical properties. This double effect will help preventing the solubilization of $\mathrm{Fe}$ and $\mathrm{Al}$, especially in the environments intrinsically at risk of ions reductions such as the very wet environments dominated by poorly drained soils.

Gy3 differs from the other two batches for a significantly higher content of almost all organic acids and sugars (Table 2). However, these concentrations would not be sufficient to represent a high organic load (i.e., fatty acids and lactose) which can lead to potential pollution problems on land spreading. The organic contaminants in both Gy1 and Gy2 were considerably lower overall, making these two batches biologically suitable by-products for re-use as amendments for agricultural soils.

\section{Variation of the Lacto-Gypsum Characteristics}

The PCA multivariate statistical analysis gives a clearer picture of the relationship between parameters for the different batches of lacto-gypsum studied. PCA analysis isolated two principal components (PC) (total variance explained: 77.2\%) covering the variables related to physico-chemical and biological parameters for the three batches (Table 4). The 1st PC (44.1\% of the total variance) was related to almost all the major nutrients, trace elements and organic compounds, while the 2 nd PC $(33.1 \%$ of the total variance) was associated with some key properties of the lacto-gypsum such as OM, Total N, DM, Ca, and pH (Table 4). The score plot provides a graphical representation of the different lacto-gypsum batches, identifying the parameters that were more associated with each other; in fact, the graphical closeness of a variable with an object in the plot showed a correlation between them. The PCA bi-plot of scores and loadings [combination of PC1 and PC2 (Figure 2)], showed a clear separation of the three lacto-gypsum batches analyzed suggesting some differences in the lacto-gypsum production process over a year pilot scale. However, each batch was associated with different parameters.
TABLE 4 | Principal component analysis (PCA): Principal component loadings.

\begin{tabular}{lcc}
\hline Variable & PC 1 & PC 2 \\
\hline Al & $-\mathbf{0 . 8 7 8 1 7 5}$ & 0.311006 \\
$\mathrm{Ca}$ & -0.025737 & $-\mathbf{0 . 7 5 4 3 5 7}$ \\
$\mathrm{Cr}$ & -0.205309 & 0.593679 \\
$\mathrm{Cu}$ & -0.094158 & 0.339475 \\
$\mathrm{Fe}$ & $-\mathbf{0 . 8 4 1 6 9 6}$ & 0.426966 \\
$\mathrm{~K}$ & $-\mathbf{0 . 8 5 6 2 6 5}$ & 0.433700 \\
$\mathrm{Mg}$ & $-\mathbf{0 . 9 2 7 2 8 2}$ & 0.237933 \\
$\mathrm{Mn}$ & $-\mathbf{0 . 9 4 6 4 2 2}$ & 0.151650 \\
$\mathrm{Na}$ & $-\mathbf{0 . 9 4 5 4 0 1}$ & 0.219671 \\
$\mathrm{Ni}$ & 0.539517 & 0.390753 \\
$\mathrm{P}$ & $-\mathbf{0 . 9 1 9 6 3 3}$ & -0.177971 \\
$\mathrm{~S}$ & 0.196456 & -0.125934 \\
Zn & $-\mathbf{0 . 8 5 3 5 1 2}$ & 0.490454 \\
Total C & $-\mathbf{0 . 6 5 5 1 8 9}$ & 0.482912 \\
Total N & 0.000709 & -0.693465 \\
OM & -0.314127 & $\mathbf{0 . 8 4 5 7 1 1}$ \\
DM & -0.035411 & $\mathbf{0 . 8 4 4 3 6 4}$ \\
pH & -0.495910 & $-\mathbf{0 . 8 6 3 0 4 6}$ \\
Lactic Acid & $\mathbf{0 . 9 1 5 8 4 8}$ & 0.348905 \\
Citric Acid & 0.169148 & $\mathbf{0 . 9 6 8 9 7 3}$ \\
Succinic Acid & $\mathbf{0 . 8 2 7 2 0 1}$ & 0.535374 \\
Formic Acid & $\mathbf{0 . 8 2 7 2 0 1}$ & 0.535374 \\
Acetic Acid & $\mathbf{0 . 8 2 7 2 0 1}$ & 0.535374 \\
Lactose & 0.362858 & \\
Galactose & 0.615961 & \\
& & $\mathbf{0 . 8 9 7 1 5 4}$ \\
\hline & &
\end{tabular}

Parameters in bold are used for PCA interpretation.

Gy2 and Gy3 are localized in opposite areas of the plot along PC1 with Gy2 closer to all parameters related to nutrient content and trace elements and Gy3 closer to the organic contaminants group (Figure 2). Although different for nature, Gy3 treatments (storage form and time) were more clustered within each other than the ones for Gy2. This suggests that between the two, Gy3 was a more refined product, more stable in terms of storage form and time. However, the higher organic acid and sugar concentration in Gy3, even if very low relative to other amendments or by-products, could be potentially perceived as problematic for land spreading. A further optimization of the procedure for lactic acid removal is needed for matrices with characteristics similar to Gy3.

Both Gy2 and Gy3 are localized in the upper quadrants of the plot along $\mathrm{PC} 2$, closer to $\mathrm{OM}$ content, but far from $\mathrm{pH}$ and $\mathrm{Ca}$, which, as expected are highly correlated variables. This suggests lower $\mathrm{pH}$ values for these two batches. On the other hand, Gyl seems to be neutral in terms of major nutrients, trace elements and organic contaminants (as is sitting on the 0 point for PC1), while it is shifted down on the plot along $\mathrm{PC} 2$, suggesting an increase of $\mathrm{pH}$ and $\mathrm{Ca}$ among others. These two parameters are key factors for the agricultural reuse of lacto-gypsum, being able to discriminate the quality of the byproduct directly at processing plant. The precipitation of $\mathrm{Ca}$, in fact, is the demonstration that the acidification treatment 


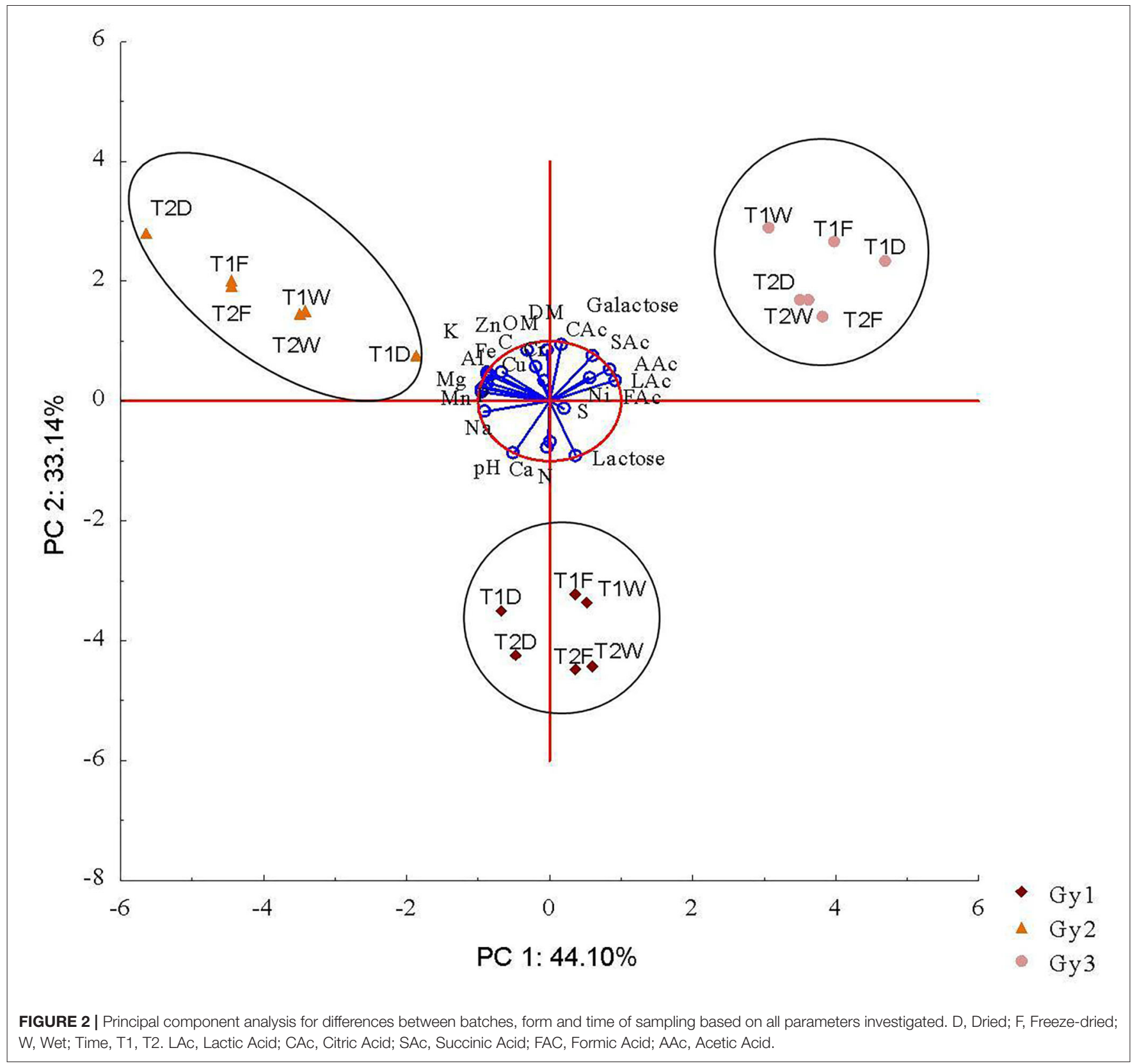

fully functioned. The adjustment of $\mathrm{pH}$ during the production process, through the dosage of $\mathrm{H}_{2} \mathrm{SO}_{4}$, not only influences the final content of $\mathrm{Ca}$ and $\mathrm{S}$ but also the concentration of other nutrients, which can be pulled out from the fermentation broth. However, some nutrients, if too high in concentration, can return in the soil in a soluble form thus being at risk of loss. Gy1 represent a good quality batch, carrying enough quantity of nutrients to be considered a good media for nutrient supply, and at the same time being able to prevent potential nutrient losses by forming insoluble complex trough the high amount of Ca present. Theoretically, the $\mathrm{Ca}$ content present in this batch can be sufficient to retain the amount of $\mathrm{P}$, by forming $\mathrm{P}-\mathrm{Ca}$ compounds, once the by-product is spread in the soil.
This will help prevent the P from leaching (Carreira et al., 2006).

Furthermore, changes in the $\mathrm{pH}$ of the final by-product, even if small, can determine its final use. Lacto-gypsum with a lower $\mathrm{pH}$ can have a higher potential if used as amendment to acidify other media such as slurry or manure prior spreading so to reduce $\mathrm{NH}_{3}$ and GHGs emissions. The batches do not particularly differ in $\mathrm{pH}$, so the three of them are equally good for this purpose. However, the dosage of $\mathrm{H}_{2} \mathrm{SO}_{4}$ used for production of Gyl seemed to be close to optimum, being able to constitute a safe, storage stable, high quality material, technologically sounded and potentially able to achieve agronomic benefit and nutrient recycling opportunities. 


\section{Practical Implications and Further Studies}

In general, this new lacto-gypsum represents a potentially suitable product for use as soil amendment or as an acidification agent for animal slurry to reduce ammonia gas emissions during land-spreading. The practical implications to take into account for both these uses are multiple.

For direct application to agricultural soils the low $\mathrm{pH}$ of lacto-gypsum represents one of the main concerns especially in histic or very acidic soils. In Ireland a significant proportion of the agricultural soils were formed from limestone parent material with naturally high $\mathrm{pH}$ status (>7.0). In this case the application of lacto-gypsum may be beneficial to reach an optimum $\mathrm{pH}$ of 6.3-7.0 (Wall and Plunkett, 2016; Bondi et al., 2020). However, on the acidic agricultural soils, such as acidic cambisols or podzols, a planned lacto-gypsum application approach is required, including soil testing, to identify current soil $\mathrm{pH}$ and nutrient concentrations (Wall and Plunkett, 2016). Research is needed to investigate the direct effect of lacto-gypsum applications on soil $\mathrm{pH}$ and the indirect effects on nutrient availability and other environmental consequences in order to develop application strategies and advice suitable for different agricultural soils.

The efficiency of lacto-gypsum as a soil amendment needs further evaluation in a field study across a range of different soil types. Such study would help evaluating the strengths and weaknesses of the lacto-gypsum use in conjunction with standard field practices such as organic and mineral fertilizer applications commonly performed in agricultural systems. This will help to develop suitable rates of application and to identify possible interactions between lacto-gypsum and other inputs applied to agricultural soils.

The possible use of lacto-gypsum as a potential acidification agent of other media, such as slurry or manure represents a technological solution which requires effective testing in respect of the health and safety procedures. Such research would enable a better understanding of the optimum ratio of lacto-gypsum to organic matter to efficiently decrease gaseous nutrients losses from the manure into the atmosphere while enhancing the soil physical, chemical and biological quality when the organic manure amended with lacto-gypsum is applied to soil.

The nature of the raw lacto-gypsum matrix post-production may present difficulties for land spreading as this by-product was difficult to handle and homogenize at small batch scale. While the raw form maintained its physico-chemical characteristics over the relatively short investigation period, further research is required to optimize its storage and spreading efficiency. This has to be coupled with a cost-benefit analysis taking into account the cost of storage vs. the cost of transformation and, or transport.

\section{CONCLUSIONS}

Conventional gypsum is commonly used as a soil amendment to improve soil quality. Other potential sources of gypsum are produced during the purification of lactic acid from complex fermentation broth coming from whey permeate dairy side streams process. In this paper, we study the physico-chemical characterization of lactogypsum produced through these alternative sources, to explore its potential as soil amendment or slurry/manure acidification media.

Our results show that the nutrient and trace element contents of the lacto-gypsum batches are within similar concentration ranges of other forms of gypsum previously tested on soils. Therefore, lacto-gypsum represents a safe material free of contaminants.

Storage form and time did not affect the main lacto-gypsum physico-chemical characteristics and indicates that this byproduct is stable in its raw state for at least 20 days when stored at $4^{\circ} \mathrm{C}$.

The optimization of the industrial process from which the lacto-gypsum is derived led to the production of a slightly heterogeneous material over 1 year pilot study. $\mathrm{Ca}$ and $\mathrm{pH}$ were flagged out as important variables to consider for production of a homogeneous by-product at pilot scale.

In general, the results obtained from this experiment are extremely promising. Lacto-gypsum proved to be a sustainable by-product, free of contaminants and could potentially be recycled back to dairy farms and soils to enhance soil quality.

This study represents an important piece of knowledge for the society as it offers the complete characterization of a new by-product, comparable to the ones commonly used to improve soil quality, and originated through the valorization of dairy whey side streams following a circular economy approach. This can be used to develop specific application strategies and advices to farmers complying with the green objectives of agricultural policies in favor of agriculture sustainability.

However, lacto-gypsum is a new product that requires to be tested in real scenarios so that limitations can be curbed with further experimentation. For example, the low $\mathrm{pH}$ of this byproduct must be considered when selecting suitable soils for application, such as soils with high $\mathrm{pH}$ levels, or when using lacto-gypsum as an acidification agent of other media prior to land spreading. A specific testing for different agricultural soils and management systems is therefore needed before the use of lacto-gypsum can become a common practice for land users.

\section{DATA AVAILABILITY STATEMENT}

The raw data supporting the conclusions of this article will be made available by the authors, without undue reservation.

\section{AUTHOR CONTRIBUTIONS}

GB conceived and designed the analysis, collected the data, performed the lab analysis, performed the stat analysis, interpreted the data, and wrote the paper. OF conceived and designed the analysis, helped with the stat analysis, contributed to writing and reviewing, and contributed providing funding. PS collected the data, performed the lab analysis, and contributed to writing and reviewing. HK conceived and designed the 
analysis, contributed to writing and reviewing, and provided funding. DW conceived and designed the analysis, helped with the stat analysis, contributed to interpret the data, contributed to writing and reviewing, and contributed providing funding. All authors contributed to the article and approved the submitted version.

\section{REFERENCES}

Amoah-Antwi, C., Kwiatkowska-Malina, J., Thornton, S. F., Fenton, O., Malina, G., and Szara, E. (2020). Restoration of soil quality using biochar and brown coal waste: a review. Sci. Total Environ. 722:137852. doi: 10.1016/j.scitotenv.2020.137852

Asakura, H. (2015). Sulfate and organic matter concentration in relation to hydrogen sulfide generation at inert solid waste landfill site-limit value for gypsum. Waste Manage. 43, 328-334. doi: 10.1016/j.wasman.2015.06.018

Ashekuzzaman, S. M., Forrestal, P., Richards, K., and Fenton, O. (2019). Dairy industry derived wastewater treatment sludge: generation, type and characterization of nutrients and metals for agricultural reuse. J. Clean. Prod. 230, 1266-1275. doi: 10.1016/j.jclepro.2019.05.025

Baligar, V. C., Clark, R. B., Korcak, R. F., and Wright, R. J. (2011). "Flue gas desulfurization product use on agricultural land," in Advances in Agronomy, eds D. L. Sparks, 51-86. doi: 10.1016/B978-0-12-387689-8.00005-9

Batool, A., Taj, S., Rashid, A., Khalid, A., Qadeer, S., Saleem, A. R., et al. (2015). Potential of soil amendments (Biochar and Gypsum) in increasing water use efficiency of Abelmoschus esculentus L. Moench. Front. Plant Sci. 6:733. doi: 10.3389/fpls.2015.00733

Bondi, G., Capra, G. F., Macci, C., Ceccanti, B., Grilli, E., Vacca, S., et al. (2016). Biochemical performance of degraded soil recovered by lake-dredged materials (LDM) as pedotechnomaterials. J. Soils Sediments. 16, 1871-1888. doi: 10.1007/s11368-016-1376-7

Bondi, G., O 'Sullivan, L., Fenton, O., Creamer, R., Marongiu, I., and Wall, D. P. (2020). Trafficking intensity index for soil compaction management in grasslands. Soil Use Manage. 1-15. doi: 10.1111/sum.12586

Byrne, E. (1979). Chemical analysis of agricultural materials: Methods Used at Johnstown Castle Research Centre, Wexford. Dublin: An Foras Taluntais.

Carreira, J. A., Vinegla, B., and Lajtha, K. (2006). Secondary $\mathrm{CaCO}_{3}$ and precipitation of $\mathrm{P}-\mathrm{Ca}$ compounds control the retention of soil $\mathrm{P}$ in arid ecosystems. J. Arid. Environ. 64, 460-473. doi: 10.1016/j.jaridenv.2005.06.003

Chen, L., and Dick, W. A. (2011). Gypsum as an Agricultural Amendment: General Use Guidelines. The Ohio State University Extension, Columbus. Available online at: http://ohioline.osu.edu/b945/index.html

Chi, C. M., Zhao, C. W., Sun, X. J., and Wang, Z. C. (2012). Reclamation of saline sodic soil properties and improvements of rice (Orizasativa) growth and yield using desulfurized gypsum in the west of Songnen Plain, north east China. Geoderma 187, 24-30. doi: 10.1016/j.geoderma.2012. 04.005

DAFF (2011). Food Harvest 2020. Dublin, Ireland. Available online at: www.agriculture.gov.ie/media/migration/foodindustrydevelopmenttrade markets/agri-foodandtheeconomy/foodharvest2020/2020FoodHarvestEng2 40810.pdf

Dick, W. A., Huo, Y., Stehouwer, R. C., Bigham, J. M., Wolfe, W. E., Adraiano, D., et al. (2006). "Beneficial uses of flue gas desulfuration by products; Examples and case studies of land application," in Land Application of Agricultural, Industrial, and Municipal by Products, eds J.F. Power and W.A. Dick (Madison, WI: SSSA Book Series.6), 505-536. doi: 10.2136/sssabookser6.c18

EC (2002). Council Decision of 19 December 2002 Establishing Criteria and Procedures for the Acceptance of Waste at Landfills Pursuant to Article 16 of and Annex II to Directive 1999/31/EC, 2003/33/EC, OJ L11, 32-36

EEC (1986). EU Council Directive 86/278/EEC of the 12th of June 1986, on the protection of the environment, and particular of the soil, when sewage sludge is used in agriculture Off. J. EC 181, 6-12.

Eurostat (2019). Raw Cows' Milk Delivered to Dairies, Milk Collection (All Milks) and Dairy Products Obtained - Annual Data of 2017. European Commission.

\section{FUNDING}

This project has received funding from the Bio Based Industries Joint Undertaking (BBI-JU) under the European Union's Horizon 2020 research and innovation programme under grant agreement No 744310 .

Available online at: https://appsso.eurostat.ec.europa.eu/nui/show.do?dataset= apro_mk_pobta\&lang=en

Farina, M. P. W., Channon, P., and Thibaud, G. R. (2000). A comparison of strategies for Ameliorating subsoil acidity: I. Long-term soil effects. Soil Sci.Soc. Am. J. 64, 652-658. doi: 10.2136/sssaj2000.6 $42652 x$

Fauziah, I., Zauyah, S., and Jamal, T. (1996). Characterization and land application of red gypsum: a waste product from the titanium dioxide industry. Sci. Total Environ. 188, 243-251. doi: 10.1016/0048-9697(96)05179-0

Finnegan, W., Goggins, J., Clifford, E., and Zhan, X. (2017). Environmental impact of milk powder and butter manufacture in the Republic of Ireland. Sci. Total Environ. 579, 159-168. doi: 10.1016/j.scitotenv.2016.10.237

Hamza, M. A., and Anderson, W. K. (2002). Improving soil physical fertility and crop yield on a clay soil in Western Australia. Aust. J. Agric. Res. 53, 615-620. doi: 10.1071/AR01099

Herrero, J., Artieda, O., and Hudnall, W. H. (2009). Gypsum, a tricky material. Soil Sci. Soc. Am. J. 73, 1757-1763. doi: 10.2136/sssaj2008.0224

Illera, V., Garrido, F., Serrano, S., and García-González, M. T. (2004). Immobilization of the heavy metals $\mathrm{Cd}, \mathrm{Cu}$ and $\mathrm{Pb}$ in an acid soil amended with gypsum-and lime-rich industrial by-products. Eur. J. Soil Sci. 55, 135-145. doi: 10.1046/j.1365-2389.2003.00583.x

Kauppila, R., and Pietola, L. (2013). "Gypsum to improve soil structure and to reduce phosphorus loss," in Proceedings-International Fertiliser Society (No. 741). Cambridge: International Fertiliser Society.

Kavanagh, I., Burchill, W., Healy, M. G., Fenton, O., Krol, D. J., and Lanigan, G. J. (2019). Mitigation of ammonia and greenhouse gas emissions from stored cattle slurry using acidifiers and chemical amendments. J. Clean. Prod. 237:117822. doi: 10.1016/j.jclepro.2019.117822

Koralegedara, N. H., Pinto, P. X., Dionysiou, D. D., and Al-Abed, S. R. (2019). Recent advances in flue gas desulfurization gypsum processes and applicationsA review. J. Environ. Manage. 251, 109572. doi: 10.1016/j.jenvman.2019.109572

Kost, D., Ladwig, K. J., Chen, L., DeSutter, T. M., Espinoza, L., Norton, L. D., et al. (2018). Meta-Analysis of gypsum effects on crop yields and chemistry of soils, plant tissues, and vadose water at various research sites in the USA. J. Environ. Qual. 47, 1284-1292. doi: 10.2134/jeq2018.04.0163

Morrissey, B., O’brien, C., Hogan, M., Hogan, E., Sawdekar, P. R., and Padamati, R. B. (2019). A method of producing lactic acid. U.S. Patent Application No. 16/324,117. Ref. WO2018029219A1. Available online at: https://patents.google. com/patent/WO2018029219A1/en

Mupambwa, H. A., Dube, E., and Mnkeni, P. N. (2015). Fly ash composting to improve fertiliser value-A review. South Afri. J. Sci. 111, 1-6. doi: $10.17159 /$ sajs.2015/20140103

Øgaard, A. F., and Brod, E. (2016). Efficient phosphorus cycling in food production: predicting the phosphorus fertilization effect of sludge from chemical wastewater treatment. J. Agric. Food Chem. 64, 4821-4829. doi: 10.1021/acs.jafc.5b05974

Oster, J. D., and Frenkel, H. (1980). Chemistry of the reclamation of sodic soils with gypsum and lime. Soil Sci. Soc. Am. J. 44, 41-45. doi: 10.2136/sssaj1980.03615995004400010010x

Peyton, D. P., Healy, M. G., Fleming, G. T. A., Grant, J., Wall, D. P., Morrison, L., et al. (2016). Nutrient, metal and microbial loss in surface runoff following treated sludge and dairy cattle slurry application to an Irish grassland soil. Sci. Total Environ. 541, 218-229. doi: 10.1016/j.scitotenv.2015. 09.053

Plaza, C., Xing, B., Fernàndez, J. M., Senesi, N., and Polo, A. (2009). Binding of polycyclic aromatic hydrocarbons by humic acids formed during composting. Environ. Pollut. 157, 257-263. doi: 10.1016/j.envpol.2008.07.016 
Ryan, M. P., and Walsh, G. (2016). The Characterisation of DairyWaste and the Potential of Whey for Industrial Fermentation. Limerick: EPA Research Report, Environmental Protection Agency, Limerick, Ireland.

Shainberg, I., Sumner, M. E., Miller, W. P., Farina, M. P. W., Pavan, M. A., and Fey, M. V. (1989). Use of gypsum on soils: A review. Adv. Soil Sci. 9, 1-111. doi: 10.1007/978-1-4612-3532-3_1

Sommer, S. G., and Husted, S. (1995). A simple model of pH in slurry. J. Agric. Sci. 124, 447-453. doi: 10.1017/S0021859600073408

Storer, D. A. (1984). A simple high sample volume ashing procedure for determination of soil organic matter. Commun. Soil Sci. Plan. 15, 759-772. doi: $10.1080 / 00103628409367515$

Sumner, M. E. (1993). Gypsum and acid soils: the world scene. Advan. Agron. 51, 1-32. doi: 10.1016/S0065-2113(08)60589-1

Toma, M., and Sumner, M. E., Weeks, G., Saigusa, M. (1999). Long-term eff ects of gypsum on crop yield and subsoil chemical properties. Soil Sci. Soc. Am. J. 63, 891-895. doi: 10.2136/sssaj1999.634891x

USEPA (1996). SW-846 Test Method 3052: Microwave Assisted Acid Digestion of Siliceous and Organically Based Matrices. Washington, DC: Environmental Protection Agency.

Walia, M. K., and Dick, W. A. (2016). Soil chemical properties, and plant growth as influenced by gypsum and Carbon amendments application. J. Soil Sci. Plant Nut. 16, 832-847.

Walia, M. K., and Dick, W. A. (2018). Selected soil physical properties and aggregate-associated carbon and nitrogen as influenced by gypsum, crop residue, and glucose. Geoderma 320, 67-73. doi: 10.1016/j.geoderma.2018.01.022
Walia, M. K., and Dick, W. A. (2019). Gypsum and carbon amendments influence leachate quality from two soils in Ohio, USA. Soil Sci.Soc. Am. J. 83, 212-220. doi: $10.2136 /$ sssaj2018.06.0220

Wall, D. P., and Plunkett, M. (2016). Major and Micro Nutrient Advice for Productive Agricultural Crops. Teagasc, Wexford, 180.

Wang, J., and Yang, P. (2018). Potential flue gas desulfurization gypsum utilization in agriculture: A comprehensive review. Renew. Sust. Energ. Rev. 82, 1969-1978. doi: 10.1016/j.rser.2017.07.029

Watts, D. B., and Dick, W. A. (2014). Sustainable uses of FGD gypsum in agricultural systems: introduction. J. Environ. Qual. 43, 246-252. doi: $10.2134 /$ jeq2013.09.0357

Conflict of Interest: HK and PS are employed by the company Glanbia Ireland Ltd.

The remaining authors declare that the research was conducted in the absence of any commercial or financial relationships that could be construed as a potential conflict of interest.

Copyright (0 2021 Bondi, Fenton, Sawdekar, Keane and Wall. This is an open-access article distributed under the terms of the Creative Commons Attribution License (CC $B Y)$. The use, distribution or reproduction in other forums is permitted, provided the original author(s) and the copyright owner(s) are credited and that the original publication in this journal is cited, in accordance with accepted academic practice. No use, distribution or reproduction is permitted which does not comply with these terms. 